\title{
PENERAPAN GOOLITAL-JECT BERBASIS STEAM UNTUK MENINGKATKAN CRITICAL THINKING SISWA PADA MATERI STRUKTUR DAN FUNGSI TUMBUHANKELAS VIII-A SMP NEGERI UNGGUL SIGLI
}

\author{
Yanti Julia \\ Guru IPA SMP Negeri Unggul Sigli \\ yantisaidi84@gmail.com
}

\begin{abstract}
ABSTRAK
Tujuan penelitian adalah untuk mengetahui pengaruh penerapan model pembelajaran Goolital-Ject berbasis STEAM dalam meningkatkan critical thinking siswa pada materi Struktur dan Fungsi Tumbuhan siswa kelas VIII-A SMP Negeri Unggul Sigli. Jenis penelitian ini adalah Classroom Action Research, yang meliputi 2 siklus, setiap siklus nya melalui tahapan perencanaan, tindakan, observasi, dan refleksi. Teknik pengumpulan data diperoleh melalui observasi, penugasan, dan wawancara, sementara alat pengumpulan data diperoleh dari butir soal tes dan rubrik penilaian, yang kemudian akan dianalisis secara kuatitatif dan deskriptif. Berdasarkan proses penelitian dalam setiap siklus, terjadi peningkatan keterampilan critical thinking siswa antar siklus, indikator nya meliputi Focusdari $63.0 \%$ meningkat menjadi 70.4 $\%$, Reasondari $48.1 \%$ meningkat menjadi $55.6 \%$, Inference dari $40.7 \%$ meningkat menjadi $51.9 \%$, Situationdari $59.3 \%$ meningkat menjadi $66.7 \%$, Clarity dari 59.3 $\%$ meningkat menjadi $63.0 \%$, and Overviewdari $55.6 \%$ meningkat menjadi $59.3 \%$. Pemahaman siswa pun mengalami peningkatan yang ditandai bertambah nya siswa yang tuntas antar siklus. Kesimpulan penelitian ini adalah model pembelajaran Goolital-Ject berbasis STEAM dapat meningkatkan critical thinking siswa pada materi Struktur dan Fungsi Tumbuhan kelas VIII-A SMP Negeri Unggul Sigli.
\end{abstract}

Kata Kunci : Goolital-Ject, pendekatan STEAM, critical thinking

\section{A. Pendahuluan}

Abad 21 dan Revolusi 4.0 telah merubah paradigma di berbagai bidang, tak terkecuali dunia pendidikan. Pembelajaran yang diharapkan adalah munculnya multi keterampilan siswa yang dapat diaplikasikan dalam kehidupan nyata, untuk mewujudkannya diperlukan kompetensi guru mendesain proses pembelajaran yang bercirikan learning skill, yaitu kegiatan pembelajaran yang di dalamnya ditandai dengan adanya kerja sama (collaboration), komunikasi (communication), serta berpikir kritis (criticalthinking) dan kreatif (creativity) dengan prinsip guru bukanlah satusatunya sumber belajar.

Menurut laporan BNSP tahun 2010 dalam Wasitohadi (BNSP 2010; Kemdikbud 2012), perubahan paradigma pendidikan diantaranya adalah (1) dari satu arah menuju interaktif (2) dari isolasi menuju lingkungan jejaring (3) dari pasif menuju aktif menyelidiki (4) dari maya/abstrak menuju konteks dunia nyata (5) dari pembelajaran pribadi menuju 
Jurnal Sosial Humaniora Sigli (JSH)

p ISSN : 2615-3688

$e$ ISSN : 2716-0270

http://journal.unigha.ac.id/index.php/JSH

pembelajaran berbasis tim. Hal tersebut mencerminkan

4 pilar pendidikan yang dicanangkan oleh UNESCO, yaitu (1) learning to know (belajar untuk mengetahui), (2) learning to do (belajar untuk melakukan), (3) learning to be (belajar untuk mengaktualisasikan diri sebagai individu mandiri yang berkepribadian), dan (4) learning to live together (belajar untuk hidup bersama).

IPA merupakan mata pelajaran kelompok wajib dan Ujian Nasional jenjang SMP yang berisikan berbagai materi kehidupan dan kontekstual, salah satu diantaranya adalah Struktur dan Fungsi Tumbuhan. Materi ini tertuang dalam KD 3.2. dan 4.2. Pencapaian keberhasilan pembelajarannya harus melibatkan keterampilan fundamental yang sesuai dengan pembelajaran abad 21, yaitu keterampilan berfikir kritis (critical thinking). Menurut Ennis dalam Cahyono (2017), "Dalam memecahkan masalah seorang pemikir kritis memiliki enam karakteristik yang dikenal dengan istilah FRISCO (Focus, Reason, Inference, Situation, Clarity, and Overview)." Keterampilan ini mencakup kemampuan mengakses, menganalisis, mensintesis informasi yang dapat dibelajarkan, dilatih, dan dikuasai. Selain itu mencakup juga keterampilan komunikasi dan informasi, memeriksa, menganalisis, menafsirkan, dan mengevaluasi bukti. Pembelajarannya juga terintegrasi dan terpadu dengan disiplin ilmu lainnya dan diharapkan adanya produk sebagai cerminan dari kompetensi keterampilan.

Proses pembelajaran yang telah berlangsung untuk memperoleh pemahaman dan keterampilan siswa sering sekali terbatasi oleh guru sebagai salah satu sumber belajar. Potensi yang dimiliki siswa tidak tereksplorasi dengan baik akibat proses pembelajaran yang tidak mengaktualisasikan siswa sebagai pemeran utama, yang pada akhirnya pencapaian kompetensi dasar yang tertuang dalam silabus tidak maksimal terwujud, mengurangi motorik dan critical thinking siswa, sementara tantangan soal Ujian Nasional yang melibatkan keterampilan berfikir tingkat tinggi tidak dapat terealisasi dari proses yang telah mereka lalui. Faktanya terdapat berbagai sumber belajar yang telah diprogramkan oleh Kemdikbud melalui Gerakan Literasi Nasional, salah satu diantaranya adalah Literasi Digital, yaitu kemampuan menggunakan teknologi dan informasi dari piranti digital secara efektif dan efisien dalam berbagai konteks, seperti akademik, karir, dan kehidupan sehari - hari.

STEAM adalah sebuah pendekatan pembelajaran yang merupakan sarana bagi peserta didik untuk menciptakan ide/gagasan berbasis sains dan teknologi melalui kegiatan berpikir dan bereksplorasi dalam memecahkan masalah berdasarkan pada lima disiplin ilmu yang terintegrasi. Jika pemecahan masalah dilakukan berdasarkan beberapa disiplin ilmu, maka akan menghasilkan sebuah solusi yang sangat tepat, tidak hanya pemecahan masalah sains namun berdasarkan konsep yang berhubungan dengan disipilin ilmu lain sehingga pemecahan masalah akan menjadi sangat menarik, efektif dan efisien (Nurhikmayati, 2019).

Berdasarkan analisis tersebut, perlu adanya perubahan gaya belajar siswa yang mengarah ke pembelajaran Abad 21, dan Revolusi 4.0. yang melibatkan learning skill, diantara nya adalah Model PjBL melibatkan literasi digital berbasis STEAM (Sains, Technology, Engineering, Art, and Mathematics), yaitu pendekatan dalam pendidikan di mana Sains, Teknologi, Teknik, Seni, dan Matematika terintegrasi dengan proses pendidikan berfokus pada pemecahan masalah dalam kehidupan sehari-hari yang nyata serta dalam kehidupan profesional, dan menghasilkan suatu karya nyata dari tahapan tersebut dengan merancang sendiri pedomannya, berbasis literasi digital (on-line). 
Jurnal Sosial Humaniora Sigli (JSH)

p ISSN : 2615-3688

$e$ ISSN : 2716-0270

http://journal.unigha.ac.id/index.php/JSH

Harapannya berfikir kritis, kreativitas, kolaboratif, komunikasi dapat menyelesaikan permasalahan berdasarkan hasil penelitian.

\section{B. Metode Penelitian}

Penelitian ini merupakan Penelitian Tindakan Kelas (Classroom Action Research), meliputi 2 siklus. Setiap siklus dilaksanakan 2 kali pertemuan. Teknik pengumpulan data terdiri dari Observasi oleh teman sejawat, Penugasan yang bertujuan memperoleh data pengetahuan dan keterampilan siswa dalam menyelesaikan tugas proyek nya berupa produk dari hasil critical thinking siswa melalui penerapan Goolital-Ject berbasis STEAM, dan Wawancara untuk menemukan kendala yang dialami siswa dalam menyelesaikan proyek nya, dan terhadap observer dilakukan setiap selesai guru melakukan tindakan dan hasilnya menjadi refleksi untuk siklus berikutnya. Alat pengumpulan data berupa butir soal dan rubrik penilaian. Analisis data berupa kuantitatif dan deskriptif.

\section{Hasil penelitian}

Kondisi pembelajaran sebelum dilakukan tindakan dan sesudah terdapat perbedaan. Saat dilakukan tindakan dengan menerapkan Goolital-Ject berbasis STEAM terjadi peningkatan critical thinking siswa. Tergambar dari antusias siswa dalam mengikuti pelajaran, melaksanakan percobaan, kritis dan kreatif dalam berfikir, suasana pembelajaran lebih bermakna, siswa menjadi aktif dan hasil belajar maksimal

Siklus I, kegiatan perencanaan yang dilakukan adalah mempersiapkan beberapa hal yang diperlukan dalam pelaksanaan penelitian yaitu: membuat RPP, membuat LKPD berupa tugas proyek, dan instrumen penelitian berupa lembar observasi untuk menilai keterampilan siswa menyelesaikan proyek dan lembar observasi untuk menilai keterampilan critical thinking siswa.

Segala sesuatu yang telah direncanakan diaplikasikan dalam kegiatan tindakan, pengerjaan proyek yang mereka lakukan dijembatani oleh penggalian sebanyak-banyaknya konsep melalui literasi digital. Disiplin ilmu sains, teknologi, enjinering, seni, dan matematik harus di polakan dalam perancangan proyek tersebut.

Berdasarkan lembar observasi pengelolaan pembelajaran pertemuan pertama dan kedua siklus pertama, berjalan sesuai rencana, proyek yang berupa rangkaian sistem transportasi tumbuhan telah berhasil dirancang dan dipresentasikan.Keterampilan critical thinking siswa terlihat dari beberapa aspek, sesuai dengan tindakan yang dilakukan, yaitu sebagai berikut :

Tabel 1 : Keterampilan critical thinking siswa siklus I

\begin{tabular}{|l|l|c|}
\hline No & \multicolumn{1}{|c|}{ Aspek } & Persentase \\
\hline 1 & Focus (Fokus) & $63.0 \%$ \\
\hline 2 & Reason (Alasan) & $48.1 \%$ \\
\hline 3 & Inference (Menarik Kesimpulan) & $40.7 \%$ \\
\hline 4 & Situation (Situasi) & $59.3 \%$ \\
\hline 5 & Clarity (Kejelasan) & $59.3 \%$ \\
\hline 6 & Overview (Peninjauan) & $55.6 \%$ \\
\hline & Total & $49.4 \%$ \\
\hline
\end{tabular}


Jurnal Sosial Humaniora Sigli (JSH)

p ISSN : 2615-3688

$e$ ISSN : 2716-0270

http://journal.unigha.ac.id/index.php/JSH

Berdasarkan hasil observasi dan refleksi, maka ada beberapa kekurangan yang ditemukan di tindakan siklus I, kegiatan proyek belum mewakili beberapa komponen STEAM, diantaranya adalah Engineriing, Art, dan Mathematics. Perlu adanya perencanaan yang lebih maksimal lagi untuk mewakili seluruh komponen STEAM.

Pelaksanaan pembelajaran pada siklus II dilaksanakan sesuai perencanaan dengan alokasi waktu 5 jam pelajaran $(2 \mathrm{x}$ pertemuan). Keterampilan critical thinking siswa terlihat dari beberapa aspek, sesuai dengan tindakan yang dilakukan, yaitu sebagai berikut :

Tabel 2 : Keterampilan critical thinking siswa siklus II

Kegiatan inti nya adalah proyek yang telah mereka selesaikan miniatur bangunan berdasarkan prinsip transportasi pada tumbuhan. Segala sesuatu pedoman untuk merancang miniatur tersebut mereka peroleh dengan mesin pencarian Google, yang dapat dijelaskan dengan konsep STEAM. Tindakan pembelajaran di siklus II, yaitu rancangan berbagai miniatur, yaitu dongkrak hidolik, jembatan hidrolik, dan lift hidrolik. Karya yang telah dikerjakan melalui kegiatan proyek telah mewakili semua komponen STEAM. Siswa mampu mengaitkan antara Science, Technology, Engineering, Arts, dan Mathematics dari miniatur dengan konsep struktur dan fungsi tumbuhan.

Joel L Klein et.al (dalam Widyantini, 2014) menjelaskan bahwa, "Pembelajaran Berbasis Proyek (Project Based Learning $=\mathrm{PjBL}$ ) adalah strategi pembelajaran yang memberdayakan siswa untuk memperoleh pengetahuan dan pemahaman baru berdasar pengalamannya melalui berbagai presentasi.

Goolital-Ject merupakan suatu pembelajaran yang memanfaatkan mesin pencarian Google sebagai literasi digital

\begin{tabular}{|l|l|c|}
\hline No & \multicolumn{1}{|c|}{ Aspek } & Persentase \\
\hline 1 & Focus (Fokus) & $70.4 \%$ \\
\hline 2 & Reason (Alasan) & $55.6 \%$ \\
\hline 3 & $\begin{array}{l}\text { Inference } \\
\text { (Menarik } \\
\text { Kesimpulan) }\end{array}$ & $51.9 \%$ \\
\hline 4 & Situation (Situasi) & $66.7 \%$ \\
\hline 5 & $\begin{array}{l}\text { Clarity } \\
\text { (Kejelasan) }\end{array}$ & $63.0 \%$ \\
\hline 6 & $\begin{array}{l}\text { Overview } \\
\text { (Peninjauan) }\end{array}$ & $59.3 \%$ \\
\hline \multicolumn{2}{|c|}{ Total } \\
\hline
\end{tabular}

dalam menyelesaikan tugas proyek siswa yang dibelajarkan menggunakan model Project Based Learning. Tujuannya untuk memperoleh pengetahuan dan kecakapan untuk menggunakan media digital, alatalat komunikasi, atau jaringan dalam menemukan penyelesaian proyek yang sudah direncanakan, dilaksanakan, dan diselesaikan. Di samping itu, pembelajaran ini mengeksplorasi kemandirian siswa dalam menyelesaikan proyeknya, guru berperan sebagai fasilitator dan motivator.

Gambar 1; Alur Goolital-Ject

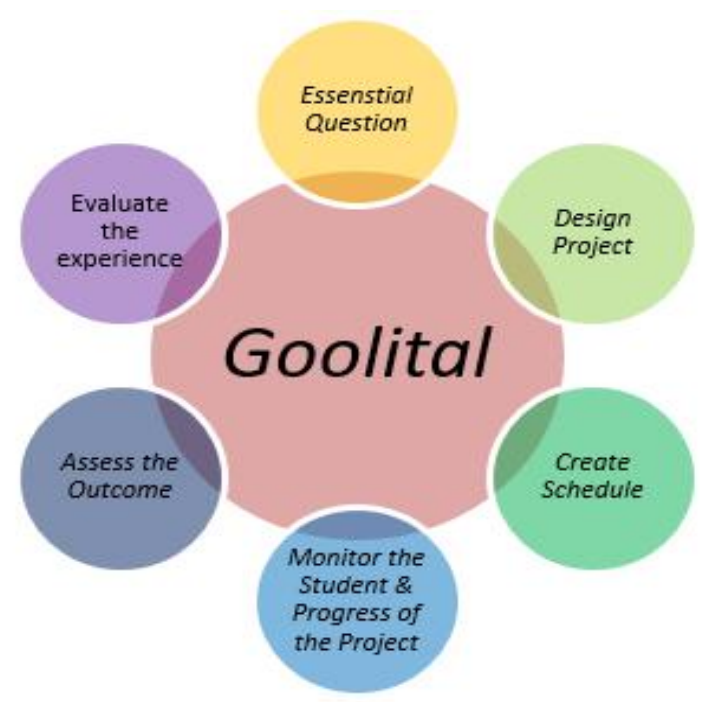


Jurnal Sosial Humaniora Sigli (JSH)

p ISSN : 2615-3688

$e$ ISSN : 2716-0270

http://journal.unigha.ac.id/index.php/JSH

sains, teknologi, enjinering, seni, dan matematika untuk memecahkan masalah dalam kehidupan sehari-hari dan mengembangkan daya cipta peserta didik (Devi dalam Saleha (2019)). Berikut penjabarannya ;

1. Sains merupakan suatu proses penemuan, cara mencari tahu tentang sesuatu, bukan hanya penguasaan kumpulan pengetahuan tentang konsep, hukum, fakta, dan prinsip.

2. Teknologi adalah suatu perangkat keras ataupun perangkat lunak yang digunakan untuk mempermudah pekerjaan dalam menyelesaikan permasalahan dalam kehidupan sehari-hari.

3. Enjinering atau rekayasa adalah pengetahuan dan keterampilan untuk mengoperasikan atau mendesain sebuah prosedur untuk menyelesaikan suatu masalah.

4. Art/Seni adalah karya manusia yang mengkomunikasikan pengalaman batin disajikan secara indah atau menarik hingga merangsang timbulnya pengalaman batin pula pada manusia lain yang menikmati.

5. Matematika adalah ilmu yang mempelajari pola dan hubungan yang digunakan sebagai bahasa bagi pengetahuan, teknologi dan rekayasa.

Jadi, kesimpulannya STEAM adalah meta-disiplin yang menerapkan pembelajaran berbasis pemecahan masalah yang sengaja menempatkan penyelidikan ilmiah dan penerapan matematika dalam konteks merancang teknologi sebagai bentuk pemecahan masalah. Tujuannya adalah mempersiapkan peserta didik agar dapat bersaing, mandiri, dan siap bekerja sesuai bakat dan bidang yang menjadi spesialisasinya.

\section{Simpulan}

Berdasarkan hasil penelitian tersebut di atas, maka penerapan Goolitalject berbasis STEAM dapat meningkatkan critical thinking siswa pada materi struktur dan fungsi tumbuhan kelas VIIIA SMP Negeri Unggul Sigli, terlihat jelas adanya peningkatan presentase indikator antara siklus I dan siklus II yaitu $49.4 \%$ menjadi $61.6 \%$.

\section{E. Daftar Pustaka}

Cahyono, Budi. Analisis Keterampilan Berpikir Krtis dalam Memecahkan Masalah Ditinjau Perbedaan Gender.Aksioma, 8:1, (Juli, 2017), 52.

Nurhikmayati, Iik. 2019. Implementasi Steam Dalam Pembelajaran Matematika.Jurnal Didactial Mathematics. Vol 1. No. 2, hal. 41-50

https://scholar.google.co.id/schola $\underline{\text { r?q=jurnal+atau+artikel+tentang+ }}$ steam\&hl=id\&as_sdt=0\&as_vis= 1\&oi=scholart

Sagita, M., \& Khairunnisa, K. (2020). ELearning for Educators in Digital Era 4.0. Budapest International Research and Critics Institute (BIRCI-Journal): Humanities and Social Sciences, 3(2), 1297-1302.

Wasitohadi. Penggunaan Teknologi Dalam Pendidikan: Tantangan Guru Pada Abad 21.

Alumni S3 Ilmu Pendidikan UNY, Dosen FKIP UKSW

Salatiga.https://www.coursehero.c om/file/43284407/MODULPEMBELAJARAN-ABAD21pdf/

Widyantini, Therasia. 2014. Penerapan Model Project Based Learning (Model Pembelajaran Berbasis 
Jurnal Sosial Humaniora Sigli (JSH)

p ISSN : 2615-3688

$e$ ISSN : 2716-0270

http://journal.unigha.ac.id/index.php/JSH

Proyek) dalam Materi Pola

Bilangan Kelas VII. Pusat

Pengembangan dan

Pemberdayaan Pendidikan dan

Tenaga Pendidikan (PPPPTK).

Artikel. Depdiknas. 